\title{
GRAMSCI E OS CONSELHOS DE FÁBRICA: NOTAS A PARTIR DOS ESCRITOS PRÉ-CARCERÁRIOS
}

\author{
Mirele Hashimoto Siqueira ${ }^{1}$
}

\begin{abstract}
RESUMO: O presente artigo trata de investigar a temática dos Conselhos de Fábrica a partir das construções de Antonio Gramsci e tem como objetivo analisar a elaboração de suas formulações em torno dos Conselhos de Fábrica a partir dos escritos pré-carcerários. Para tanto, parte-se da hipótese de que a teorização dos Conselhos de Fábrica pelo autor "sardo" representou uma significativa construção teórico/prática para seu gradual e sucessivo "acerto de contas" com a influência idealista neo-hegeliana de sua formação inicial e, por conseguinte, para sua aproximação com o pensamento marxista. A metodologia empregada se voltou para o recurso da pesquisa bibliográfica e de caráter qualitativo, buscando o contato direto com os escritos de Gramsci. As principais inferências obtidas são de que os Conselhos de Fábrica representam um esforço teórico fundamental de Gramsci para elaborar uma teoria revolucionária e se circunscrevem no centro do processo de transição para sua maturidade intelectual.
\end{abstract}

Palavras-chave: Gramsci; Conselhos de Fábrica; Comissões Internas de Fábrica.

ABSTRACT: The present article tries to investigate the theme of the Factory Councils from the constructions of Antonio Gramsci and its objective is to analyze the elaboration of its formulations around the Factory Councils from the precarcerial writings. To this end, it is assumed that the theorizing of the Factory Councils by the Sardinian author represented a significant theoretical/practical construction for his gradual and successive "reckoning" with the idealist neo-Hegelian influence of his initial formation and, therefore, for its approximation with Marxist thought. The methodology used turned to the resource of bibliographical research and qualitative character, seeking the direct contact with the writings of Gramsci. The main inferences obtained are that the Factory Councils represent a fundamental theoretical effort by Gramsci to elaborate a revolutionary theory and are circumscribed at the center of the process of transition to its intellectual maturity.

Keywords: Gramsci; Factory Advice; Internal Commissions of Factory.

\section{INTRODUÇÃO}

Tratar de investigar a temática dos Conselhos de Fábrica a partir das construções de Antonio Gramsci é tarefa que exige e/ou demanda resgatar o pano de fundo histórico - ainda que em linhas gerais e introdutórias - em que se assenta o cenário da trajetória política, intelectual e prática do autor "sardo". A contextualização destes elementos é o que permite (re)colocá-lo em seu tempo e em seu espaço, oportunizando uma interpretação assertiva em torno de suas elaborações teóricas. É assim que o contextualismo social oferece possibilidades para apreender o autor como um sujeito político que se relaciona - direta e verticalmente - com as circunstâncias sociais e com os acontecimentos históricos de sua própria época: levar em conta este contextualismo do autor é de tamanha feita se o que se pretende é

\footnotetext{
${ }^{1}$ Mestranda do Programa de Pós-Graduação em Serviço Social da Universidade Estadual do Oeste do Paraná (UNIOESTE), campus de Toledo; bolsista da Coordenação de Aperfeiçoamento de Pessoal de Nível Superior (CAPES); mirelehashimoto@hotmail.com.
} 
investigar os elementos fundamentais para a (re)construção de suas produções teóricas, numa verdadeira simbiose de aspectos conjunturais e estruturais e de intencionalidades pretendidas pelo próprio autor. É esta configuração que pode demarcar e/ou trazer à baila suas contribuições teóricas a fim de disponibilizála como ferramenta a mais para a luta dos revolucionários de nosso tempo (CARDOSO; SILVA; NERES, 2016).

É neste espírito que o presente artigo está organizado a partir de duas sessões: 1) a primeira buscará reconstruir os primeiros passos da trajetória política de Gramsci, com vista a caracterizar suas primeiras e principais influências intelectuais. Trazer para o centro do debate esta inferência é importante para apreender dialeticamente a relação de condições objetivas postas e de percurso de sua trajetória; 2) a segunda sessão desenvolverá, a partir da confluência com a trajetória política do autor "sardo", sua teorização prática em torno dos Conselhos de Fábrica. Partido da necessidade de se transformar as Comissões Internas de Fábrica em Conselhos de Fábrica no período do "biennio rosso", Gramsci sinalizava a urgência de construção de um Estado socialista. Traduzir os sovietes russos para o cenário da Itália evidenciava, pois, a tarefa a qual Gramsci pretendia construir e/ou elaborar quando de sua preocupação em tratar dos Conselhos de Fábrica, veiculando-a através do L'Ordine Nuovo.

\section{A FORMAÇÃO POLÍTICA INICIAL DE ANTONIO GRAMSCI: DO IDEALISMO NEO- HEGELIANO À FUNDAÇÃO DO L'ORDINE NUOVO}

Ainda que a existência de vários trabalhos publicados se ocupe suficientemente de indicar os principais períodos da trajetória política de Antonio Gramsci - a exemplo de Coutinho (1992) e de Neres (2012) -, tornar a reafirmar estes momentos é de fundamental importância para capturar e resgatar o período histórico das construções do autor "sardo". Assim é que, tratar de colocar no centro do debate a temática dos Conselhos de Fábrica a partir de Gramsci, implica na restauração teórica do cenário histórico da Itália do século XX, haja vista a implicação das condições objetivas da Itália e, em particular, de Turim, para o desenvolvimento de suas elaborações teóricas.

Embora seja consenso tácito que o início das atividades políticas de Gramsci tenha se dado a partir de 1913, com sua filiação ao Partido Socialista Italiano (PSI), seu aprendizado político têm sua gênese desde muito antes: se engaja a partir das desigualdades e das injustiças vivenciadas durante o período em que residia na Sardenha. Nascido em Ales, em 1891, Gramsci experimentou as profundas dificuldades típicas das camadas do Sul da Itália (COUTINHO, 1992). É referência à obra Fiori (1979) para tratar desta questão, seja porque trata de circunscrever a face humana pouco conhecida do autor "sardo", seja pela riqueza de detalhes que traz à baila para reconstruir a vida e o desenvolvimento do pequeno "Nino". Nesse sentido é que, seguindo na esteira de seus trilhos, as condições objetivas da família Gramsci, no início do século XX, eram bastante semelhantes às das demais famílias da Sardenha: a avassaladora miséria do Sul 
em relação ao Norte do país denunciava a adoção de uma política giolittiana ${ }^{1}$ favorecedora dos industriais nortistas. Gramsci - atravessado pelas grandes dificuldades financeiras da família durante sua infância e sua adolescência - teve de abandonar os bancos escolares, retomando os estudos institucionais apenas dois anos mais tarde (FIORI, 1979). É emblemática deste período a primeira revolta que o autor "sardo" sente e que se deixa aflorar: passa a viver ' [...] instintivamente a sua rebelião contra os ricos, porque compreende que o filho do açougueiro, do farmacêutico, do comerciante de tecidos pode estudar, enquanto sua família não tem o dinheiro suficiente para mandá-lo à escola" (LAJOLO, 1982, p. 19).

Associado a este instinto de revolta, Gramsci teve seus primeiros contatos com a imprensa socialista a partir da influência de seu irmão mais velho, Gennaro. Quando da estada de Gennaro em Turim, para o cumprimento do serviço militar, o filho mais velho de Francesco e de Guiseppina tratava de enviar exemplares de folhetos e de jornais "subversivos" - em particular, do Avanti!, órgão oficial do Partido Socialista - para Gramsci (FIORI, 1979). Assim é que, incitado e/ou motivado pelo irmão mais velho, Antonio pôde tratar de desenvolver o espírito de novas ideias: sua aproximação com o socialismo italiano tendeu a se tornar ainda mais propensa com sua mudança para a província de Cagliari, para a conclusão dos estudos escolares. Na capital da Sardenha, assume a posição e/ou o cargo de tesoureiro da Câmara do Trabalho - “"...] uma espécie de coordenação sindical em nível municipal [...]” (COUTINHO, 1992, p. 1) - e inicia sua participação nas reuniões do movimento socialista local, ainda que este movimento, na época, fosse marcado por traços abastadamente regionalistas e autonomistas. (COUTINHO, 1992). É assim que desenvolve um intenso espírito "sardista" que chega a se expressar por meio da defesa da luta de independência do Sul em relação Norte do país como suposto para a solução da "questão meridional”. Tal concepção será superada somente a partir de sua ida para Turim, donde perceberá que as dificuldades enfrentadas pelos camponeses do Sul (penúria, miséria, pobreza, pauperismo) são as mesmas dificuldades enfrentadas pelos operários do Norte: a “questão meridional” não haveria de ser solucionada pela luta mecânica de independência do Sul em relação ao Norte do país, mas antes pela união dos camponeses sulistas e dos operários nortistas para a instauração de um novo tipo de Estado - necessariamente, aquele que estende as bases para o "Estado operário e camponês" (FIORI, 1979). É esta transição de ocupação de ideias de caráter e/ou de espírito puramente regionalistas para as de cunho mais nacionais que Rapone (2014) chamará - inclusive - de início do processo de "desprovincianização de um jovem sardo".

Em 1911, Gramsci é admitido numa seleção de bolsas ofertada pelo Colégio "Carlos Alberto" para cursar a Universidade de Letras de Turim (FIORI, 1979). É nesse mesmo ano que passa a residir na capital do Piemonte e é aí que

[...] inicia a sua educação política prática. A sua experiência política até então se resumia a leitura do Avanti! e à defesa do autonomismo sardo, sem, contudo, uma atuação política efetiva. É quase certo que Gramsci já compartilhasse uma noção não muito precisa de socialismo antes de sua adesão formal ao PSI [em 1913], pois frequentava as reuniões do movimento socialista de Cagliari (já tendo travado um contato superficial com alguns escritos de Marx), na época em que cursou o secundário nessa cidade; mas o vago socialismo defendido por Gramsci era mais "sardismo" do 
que propriamente socialismo. É somente a partir do início de sua vida universitária, quando passa a residir em Turim, que o contato com as lutas travadas pelo movimento operário turinense fornecerá concreticidade ao projeto socialista gramsciano (NERES, 2012, p.68).

É certo que a formação inicial de Gramsci foi atravessada e/ou influenciada pelo movimento idealista neo-hegeliano, tão em voga na Itália do século XIX e XX, e expresso - sobretudo - pelas figuras intelectuais de Benedetto Croce e de Giovanni Gentile: esse movimento "[...] surgiu como uma reação à hegemonia do positivismo nos círculos culturais e filosóficos da Itália de fins do século XIX. Propondo a recuperação da dialética hegeliana, [...] reivindica a preponderância do espírito sobre o mundo objetivo e da vontade sobre o determinismo dos fatos" (NERES, 2012, p. 68-69, grifos do autor). O idealismo neohegeliano inspirou fortemente a formação inicial do jovem Gramsci; é com base neste alicerce que se acentuará a importância atribuída pelo autor "sardo" ao papel da cultura e da subjetividade ${ }^{2}$ na transformação da realidade, em detrimento das condições objetivas e/ou dos fatos materiais e concretos: Gramsci ainda estava diante de uma visão idealista que só será superada pelo seu processo de transição para a maturidade ${ }^{3}$ a partir do contato direto com a herança leniniana quando de sua estada em Moscou, em 1922. Foi exata e contraditoriamente - no entanto - a influência neo-hegeliana presente durante sua formação inicial, que permitiu o autor "sardo" superar o fatalismo dominante presente no centro do PSI (NERES, 2012; COUTINHO, 1992). Ora, quando de sua filiação no ano de 1913, o Partido Socialista estava formado a partir de duas correntes distintas: a maximalista e a reformista. Na primeira

[...] era dominante entre os dirigentes socialistas italianos uma concepção positivista-evolucionista do marxismo; e essa concepção servia como uma luva para justificar ideologicamente a prática política imobilista, fatalista, que predominava então nas correntes em que se dividia a maioria do PSI. [...] os principais ideólogos do PSI entendiam a revolução proletária como o resultado de uma inexorável lei do desenvolvimento econômico: o progresso das forças produtivas, aguçando a polarização de classe e conduzindo a crises de tipo catastrófico, levaria fatalmente, em dado momento, a um colapso do capitalismo, com a conseqüente irrupção da insurreição proletária (COUTINHO, 1992, p. 4).

$\mathrm{Na}$ segunda, a defesa das reformas propostas no interior da ordem capitalista era a bandeira representativa da fração reformista do PSI. Nesta fração, poder-se-ia atentar para uma espécie de confusão entre reforma e socialismo, numa ingênua convicção de que as reformas levariam, mais cedo ou mais tarde, a mecânica instauração do socialismo. É no bojo de disputa entre a corrente maximalista e a corrente reformista que Gramsci ingressa no PSI negando, desde o início, seu "determinismo econômico". A influência idealista neo-hegeliana de sua formação é o que permite combater o fatalismo presente nas concepções políticas - dos maximalistas e dos reformistas - do PSI (COUTINHO, 1992):

É quase paradoxal dizer, mas foi graças à sua interlocução crítica com Benedetto Croce e Giovanni Gentile que Gramsci pôde fugir a leitura positivista de Marx então hegemônica no PSI (e mesmo no marxismo europeu em geral, com exceção de Lênin e de Rosa Luxemburgo) e construir uma concepção marxista totalmente original e inovadora dentro do movimento socialista italiano (NERES, 2012, p. 69). 
É preciso insistir que a superação com o idealismo neo-hegeliano da formação inicial de Gramsci se dá de maneira gradativa, se contemplando inteiramente apenas a partir de sua estada na Rússia; em particular, em Moscou. No período precedente a 1922, é possível - no entanto - tornar a iniciar a observação em torno desta gradação com sua aproximação aos acontecimentos de 1917: "A partir desse momento, e ao longo do resto de sua vida, a Revolução Russa liderada por Lênin e pelos bolcheviques fornecerá a matriz ideológica que conformará definitivamente o processo de assimilação gramsciana do pensamento de Marx” (NERES, 2012, p. 70). É certo que esta primeira aproximação não se dá sem a ausência de algumas limitações, haja vista a influência de sua formação idealista inicial: exemplo emblemático desta própria limitação é o artigo intitulado "A Revolução contra 'O capital”, publicado no Avanti! e datado em 24 de dezembro de 1917; nele Gramsci afirma que a Revolução de Outubro é a expressão da vontade subjetiva - e esta, acreditava ele, era o próprio motor de desenvolvimento de toda a história humana - contra o determinismo dos fatos econômicos. Assim é que, não é demasiado reforçar, que a superação com idealismo neo-hegeliano herdado de sua formação inicial não se dá de imediato a partir do contato primário com o episódio da Revolução Russa e com os textos de Lênin, mas antes a partir de uma aproximação gradual e/ou sucessiva a este próprio arcabouço, que promoverá o "acerto de contas" definitivo com a influência idealista neo-hegeliana a contar de sua estada na grande Moscou (NERES, 2012). Os esforços contínuos de Gramsci para demarcar a necessidade de se construir uma nova cultura e de se organizar uma intensa penetração cultural para organizar as condições subjetivas para a transformação da realidade, passam a ser gradativamente combinadas - a partir da influência da Revolução Russa - com a também necessidade de se analisar as mediações do real e da realidade concreta (COUTINHO, 1992). Eis o momento de precisão cirúrgica que trataria de abrir um novo caminho na trajetória política, intelectual e - sobretudo - prática do autor "sardo": a fase na qual, "[...] juntamente com seus companheiros do seminário L'Ordine Nuovo, ele se coloca como meta 'traduzir Lênin em italiano', ou seja, analisar concretamente a realidade nacional de seu país para nela descobrir elementos capazes de viabilizar a criação de um Estado proletário, de tipo soviético" (COUTINHO, 1992, p. 10). Assim é que a observância de dois elementos centrais permite indicar o avanço na definição da elaboração política de Gramsci:

1) o deslocamento ideológico progressivo de Gramsci, que se afasta de sua formação cultural idealista inicial em direção à assimilação do pensamento marxista [mediado por Lênin]; [e] 2) a participação no movimento dos conselhos de fábrica, que fornece a experiência seminal para a elaboração de sua teoria política revolucionária (NERES, 2012, p. 67).

A confluência destes elementos levará Gramsci - mais adiante - a promover a cisão com o reformismo do PSI e a ingressar na fundação do Partido Comunista Italiano (PCI). Considerar o período de fundação da revista L'Ordine Nuovo por Gramsci e por seus colegas de Universidade (Angelo Tasca, 
Umberto Terracini e Palmiro Togliatti), em 1919 - no intervalo deste período - é, no entanto, de grande valia para adentrar no seio do ativismo do movimento operário turinense e da teorização prática dos Conselhos de Fábrica, por Gramsci, na Itália do século XX. A Revolução de Outubro havia evidenciado para o autor "sardo", a preocupação com a elaboração de um terreno para uma prática revolucionária: ora, com “[...] a revolução soviética e, mais amplamente, com o final da guerra mundial, coloca-se na ordem do dia - em toda a Europa - a questão do socialismo" (COUTINHO, 1992, p. 13). É assim que os esforços para a elaboração de uma teoria revolucionária passam a fazer parte das construções teóricas e intelectuais de Gramsci. O L'Ordine Nuovo terá, pois, exatamente a função de estender as bases para estruturar os supostos da revolução socialista no cenário da Itália a partir da defesa da necessidade de se consolidar os Conselhos de Fábrica (NERES, 2012).

\title{
2 OS CONSELHOS DE FÁBRICA NOS ESCRITOS PRÉ-CARCERÁRIOS
}

Nos anos inicias de fundação do L'Ordine Nuovo, os artigos destinados a publicação eram - em sua grande maioria - de autoria de Gramsci e de Tasca. Desde sua chegada em Turim, foi Tasca (filho de um operário socialista) que havia inspirado Gramsci a se aproximar das lutas dos operários de Turim: as lutas dos jovens socialistas turinenses - naquele momento - eram atravessadas por uma espécie de ação cultural. Gramsci, trazendo na bagagem sua herança idealista neo-hegeliana, se aproximou de Tasca e compartilhou das mesmas inquietações. Após a fundação da revista L'Ordine Nuovo, no entanto, parece se observar e/ou se ascender à cena uma certa e crescente discordância de ideias entre Gramsci e Tasca (RAPONE, 2014).

\begin{abstract}
Em Gramsci está amadurecendo uma sensibilidade nova e particular para os temas do presente, uma visão original do nexo cultura-política e das formas de organização do mundo operário, ao passo que Tasca inclina-se por uma ação cultural ainda concebida segundo as modalidades do passado, como fortalecimento interior do sujeito e contribuição para a compreensão da realidade [...] Não está em discussão a admissão da Revolução Russa como ponto de referência e do comunismo como novo horizonte da ação socialista, mas, para Tasca, o bolchevismo é um elemento que se acrescenta ao campo da reflexão, ao passo que, para Gramsci, torna-se fundamental identificar os aspectos dele nos quais se pudesse basear a tradução na Itália da experiência revolucionária russa (RAPONE, 2014, p. 117).
\end{abstract}

O L'Ordine Nuovo, de início, se centrará nas preocupações “culturalistas” de Gramsci e de seus companheiros de fundação. A "reviravolta" na direção e/ou no ordenamento do semanário será datada no marco de 21 de junho de 1919 (sétimo número da revista), episódio que circunscreve o artigo "Democracia Operária", de autoria de Gramsci, e que institui o intitulado "golpe de Estado redacional do número 7" - apoiado por Togliatti e Terracini - em contraposição às ideias de Tasca. É a publicação deste artigo que assinala o distanciamento com a orientação "culturalista" inicial da revista e abre uma nova fase para o L'Ordine Nuovo: necessariamente àquela que imprime uma nova direção ao semanário, 
demarcando a preocupação de se ocupar daquilo que acontecia - efetiva e concretamente - na realidade das massas operárias turinenses (RAPONE, 2014).

O ponto verdadeiro, porém, é que se tem um distanciamento não só em relação à orientação seguida pelo jornal nos primeiros tempos, mas também ao modo como o próprio Gramsci concebera até pouco antes a função educativa que devia acompanhar a iniciativa política do intransigentismo socialista (RAPONE, 2014, p. 120).

Assim é que a elaboração gramsciana em torno dos Conselhos de Fábrica de que - a partir de então - se ocupará as publicações do L'Ordine Nuovo, demarca uma inovadora inferência: a de fazer do semanário, bases para a expansão e/ou para a ampliação do movimento dos Conselhos de Fábrica em direção a insurreição da revolução na Itália, articulando cultura e política - através da absorção gradual da influência da Revolução Russa por Gramsci. "Percebidas as potencialidades dos conselhos de fábrica, L'Ordine Nuovo surge como pólo de agregação e expansão do movimento quando este apenas se iniciava" (DEL ROIO, 2005, p. 42). Inspirado pelos acontecimentos de 1917, Gramsci procurará transplantar para o cenário da Itália o "fazer como na Rússia”, isto é: procurava responder ao seguinte problema:

\begin{abstract}
Como dominar as imensas forças sociais que a guerra desencadeou? Como discipliná-las e dar-lhes uma forma política que tenha em si a virtude de desenvolver-se normalmente, de completar-se continuamente, até tornar-se a ossatura do Estado socialista no qual se encarnará a ditadura do proletariado? Como ligar o presente ao futuro, satisfazendo as urgentes necessidades do presente e trabalhando de modo útil para criar e "antecipar" o futuro? (GRAMSCI, 2004, p. 245).
\end{abstract}

Gramsci inicia a "Democracia operária" com esta indagação. Para o autor "sardo", o papel desempenhado pela educação política é fundamental para organizar, potencializar e disciplinar a classe proletária para substituir o Estado burguês: somente com o trabalho de articulação e de educação das massas desordenadas é que se torna possível prepará-las para colocá-las na direção de contraposição ao Estado burguês. O centro da vida proletária está localizado na fábrica; por esse motivo, a construção de um novo tipo de Estado deveria começar - exatamente - por esse próprio lócus. Para Gramsci, o Estado socialista já existia potencialmente e/ou já estava colocado a partir de um embrião institucional, qual seja: as Comissões Internas de Fábrica. As Comissões Internas não podem ser confundidas com os Sindicatos Profissionais. Em os "Sindicatos e Conselhos", artigo de Gramsci ao L'Ordine Nuovo datado em 11 de outubro de 1919, o autor "sardo" trata de esboçar esta simbiose: os Sindicatos se identificam com uma espécie de organização proletária parametrada e/ou limitada pelo próprio domínio do capital, se instituindo - portanto - como instituições funcionais ao modo de organização da produção capitalista. Por essa razão, poder-se-ia reiterar que os Sindicatos não podem fornecer as bases para o desenvolvimento do Estado de tipo proletário, haja vista seus limites institucionais como órgão que representa a conformação e/ou o apaziguamento entre capital e trabalho (GRAMSCI, 2004). Apesar das Comissões Internas também se constituírem - em certa medida - em mecanismo de natureza sindical, 
[...] tinham a finalidade principal de garantir e defender, no local de trabalho, os direitos dos trabalhadores (à participação nos prêmios de produção, a condições adequadas de trabalho, etc.) Os dirigentes da Comissão deveriam ser eleitos pelos operários sindicalizados; eles eram, assim, os delegados do sindicato de categoria no interior da empresa, já que eram indicados diretamente pelas direções sindicais. Para usar um termo que entraria em moda mais tarde, a Comissão era uma simples "correia de transmissão" do sindicato, gozando de escassa autonomia (COUTINHO, 1992, p. 15).

As Comissões Internas de Fábrica - apesar de suas limitações - evidenciam uma inferência fundamental para o autor "sardo": a necessidade de organizar os trabalhadores na fábrica - isto é, em seu conjunto social - e não apenas em sua segregação por categoria profissional, como reitera os Sindicatos. Neste momento, os Sindicatos e o Partido Político aparecem ainda - especialmente em " $O$ Conselho de Fábrica", artigo datado em 5 de junho de 1920 -, como instituições que não superam o Estado burguês; podem representar e fornecer atos de libertação que o conjunto da classe trabalhadora obterá ao longo do curso de seu processo revolucionário, mas - por si só - são mecanismos nascidos no campo da democracia burguesa e, por conseguinte, da liberdade política (GRAMSCI, 2004). Gramsci transitará dos Conselhos de Fábrica para o Partido Político somente em tempos futuros - momento em que observa que o movimento dos Conselhos de Fábrica, durante o "biennio rosso", fracassará devido à sua falta de apoio pelo PSI e de sua impossibilidade de espraiamento por toda a Itália. A experiência dos Conselhos de Fábrica para Gramsci tem - no entanto - demasiada importância para fazê-lo avançar em suas construções teóricas (NERES, 2012).

Assim é que, naquele momento ordinovista, para o autor "sardo" - em "Os problemas das Comissões Internas", de agosto de 1919 -,

\begin{abstract}
Ele [o problema das comissões internas] é, para nós, o primeiro elo da cadeia histórica que leva à ditadura do proletariado e ao comunismo, no que se refere aos operários fabris. Mesmo na forma tosca e primitiva com que se apresentam atualmente, tais comissões correspondem a este princípio afirmado nas revoluções da Rússia e da Hungria: o de que a luta de classe, no período atual da história da indústria capitalista, realiza-se em um novo tipo de organização proletária, que se baseia na fábrica e não na categoria profissional [...] Nela [comissão interna], portanto, realizam-se embrionariamente todos os princípios que irão informar a Constituição do Estado dos Conselhos; nela se realiza a democracia operária (GRAMSCI, 2004, p. 272).
\end{abstract}

O embrião institucional do Estado socialista - dado pelas Comissões Internas de Fábrica - deveria avançar e/ou se tornar maduro a partir de sua transformação em Conselhos de Fábrica: esta é, pois, a ideia sintetizadora de toda a teorização prática de Gramsci em torno dos Conselhos; “[...] o processo revolucionário emerge na fábrica e culmina na edificação do Estado Socialista” (NERES, 2012, p. 73). Ora, tratava de se fazer com que as Comissões se transformassem num organismo de representação de todos os trabalhadores da fábrica - necessariamente, os Conselhos. Para tanto, a realização desta tarefa exigia a congruência de dois elementos fundamentais: 1) em primeiro lugar, era necessário que todos os trabalhadores tivessem direito a voto e a ser votado para representar a Comissão, independentemente de 
serem sindicalizados ou não; 2) em segundo lugar, as Comissões deveriam ser organizadas a partir de equipes: os trabalhadores de cada seção deliberariam seus próprios representantes e, por conseguinte, cada um dos representantes de cada seção tornariam a se reunir em seu conjunto - construindo coletivamente um comitê geral. Com efeito, cumpridas essas modificações, poder-se-ia afirmar que a Comissão Interna se transformaria em Conselho de Fábrica (COUTINHO, 1992). Ainda no artigo "Sindicatos e Conselhos" - de 11 de outubro de 1919 - Gramsci afirma que o Conselho de Fábrica é o verdadeiro modelo do Estado proletário: é esta forma de organização que introduz o espírito de solidariedade de classe entre os trabalhadores e é o lócus no qual se torna possível desenvolver uma educação recíproca e uma unidade orgânica entre os trabalhadores. O espaço da fábrica não é senão o lugar que estende o terreno para a ação política (GRAMSCI, 2004).

Em artigo intitulado com o mesmo nome "Sindicatos e Conselhos", de 12 de junho de 1920, Gramsci torna a esboçar novamente a relação entre Sindicatos e Conselhos. Os Sindicatos são uma espécie de organismo capaz de firmar acordos e/ou de negociar a venda da força de trabalho: força o empresário a assumir uma legalidade com o operário, ainda que em troca da aposta da capacidade dos sindicatos de garantirem as obrigações, no processo produtivo, por parte dos operários. Assim é que a legalidade industrial - característica dos Sindicatos Profissionais - possibilita melhorar as condições materiais e de trabalho da classe proletária; essa legalidade, entretanto, deve ser tomada como necessária - e não perpétua - e deve ser colocada na direção de favorecer a correlação de forças em favor dos próprios proletários: é só então que os Sindicatos, ainda que instituídos pela legalidade industrial, podem potencializar uma disciplina revolucionária (GRAMSCI, 2004).

O conselho é a negação da legalidade industrial: tem como meta negá-la a cada instante, conduzir
incessantemente a classe operária à conquista do poder industrial, fazer com que a classe operária
se torne fonte deste poder. O sindicato é um elemento da legalidade e deve propor que seus filiados
a respeitem. O sindicato é responsável perante os industriais, mas o é na medida em que é
responsável perante seus filiados: ele garante ao operário e sua família a continuidade do trabalho e
do salário, ou seja, do pão e do teto. O conselho, por sua espontaneidade revolucionária, tende a
desencadear a cada momento a guerra das classes; o sindicato pela sua forma burocrática, tende a
não permitir que a guerra de classe seja jamais desencadeada. As relações entre as duas instituições
devem ter com objetivo criar uma situação na qual se evite que um impulso caprichoso do
conselho determine um passo atrás da classe operária, uma sua derrota, isto é, uma situação na qual
o conselho aceite e faça sua a disciplina do sindicato; mas o objetivo é também criar uma situação
na qual o caráter revolucionário do conselho tenha uma influência sobre o sindicato, funcione
como um reagente que dissolva a burocracia e o burocratismo sindicais [...] As relações entre
sindicato e conselho só podem ser estabelecidas do seguinte modo: a maioria, ou uma parte
substantiva dos eleitores do conselho, deve ser filiada ao sindicato. Qualquer tentativa de ligar as
duas instituições através de relações de dependência só pode levar á aniquilação de ambas
(GRAMSCI, 2004, p. 370-371).

Os Conselhos de Fábrica são um mecanismo e/ou órgão de necessidade histórica da classe operária; neles, o conjunto de todos os trabalhadores pode participar ativamente - diferente dos Sindicatos, em que apenas os filiados têm direito a voz. É somente quando os Sindicatos tratarem de assumir uma 
disciplina que revele a necessidade da revolução proletária para o próprio conjunto da classe trabalhadora e quando se posicionar na contramão da subordinação e/ou da servidão ao capital, é que podem fornecer condições agregadoras para a luta revolucionária (GRAMSCI, 2004).

A transformação das Comissões Internas em Conselhos de Fábrica indicava, para Gramsci, uma mudança necessária e essencial em sua função. Os Conselhos não são órgãos representativos e de luta por interesses particulares e imediatos da classe trabalhadora, como é o caso dos Sindicatos. Os Conselhos são os instrumentos - e este é um ponto nodal de toda a reflexão gramsciana - que permitem o trabalhador se elevar da condição de assalariado à de produtor. Ora, se os Sindicatos tratam de negociar as condições de trabalho e de vida dos trabalhadores no terreno e/ou na ótica do assalariamento, os Conselhos de Fábrica circunscrevem a classe proletária como parte indispensável do processo de trabalho (COUTINHO, 1992). É o proletário que coloca em movimento o processo produtivo e condensa o objeto fabricado; “[...] a capacidade de se conceber desse modo, ou seja, como parte integrante do trabalhador coletivo, é algo assegurado pela organização do Conselho de Fábrica tal como Gramsci a prevê” (COUTINHO, 1992, p. 16). Sua constituição era o que permitia o trabalhador se apropriar do processo de produção, estabelecendo, no interior da fábrica, um poder democrático e, na produção, um controle operário. É este poder proletário que, autogestacionando a produção na fábrica, se expandiria posteriormente ao próprio controle do Estado.

Em síntese:

O conselho de fábrica [...] rompe com essa subordinação dos operários aos imperativos da reprodução do capital, na medida em que procura estabelecer o controle operário sobre a produção e elevar a consciência proletária da condição de trabalhador assalariado àquela de "produtor": competia ao conselho de fábrica a tarefa pedagógica de desenvolver entre os operários a consciência ético-política do "produtor", promovendo a educação técnica, administrativa e política para a direção do processo produtivo e do Estado. Na verdade, na gênese da elaboração política de Gramsci, os conselhos de fábrica representavam o próprio instrumento estratégico de construção da nova ordem socialista. O estabelecimento do controle operário sobre a produção e a elevação da consciência política postos em marcha pelos conselhos de fábrica já sinalizavam a transição rumo a um ordenamento socialista das relações sociais (NERES, 2012, p. 72-73).

Com esta elaboração, Gramsci pretendia traduzir os sovietes russos para o cenário da Itália, retomando as experiências históricas da Rússia de 1905. Ora, saudando os acontecimentos de 1917 e seu líder revolucionário (Lênin), o autor "sardo" inicia sua aproximação com a herança leniniana e é fazendo “[...] analogias com os shop-stewards ingleses, com os räte alemães e, principalmente, com os soviet da Rússia, [que] o movimento [dos Conselhos] insere-se no processo em marcha da revolução socialista internacional" (DEL ROIO, 2005, p. 42). A agitação do movimento operário no final da década de 1910 ganhava novo fôlego em vários países desenvolvidos devido à irrupção da Revolução Russa de 1917. Na Itália, este movimento se expressava com grande força no Norte do país, em particular, em Turim (Piemonte) - centro urbano e industrializado. Em agosto de 1917, uma grande revolta tomou as ruas da 
cidade: o desaparecimento do pão do mercado, a insatisfação com a participação da Itália na guerra e a intensa exploração dos trabalhadores nas fábricas, levou a insurreição do conflito; seu movimento tinha uma única finalidade: destruir. Na ocasião, 50 homens foram mortos, mais de 200 ficaram feridos e dirigentes da seção turinense do PSI foram presos. É nesta circunstância que Gramsci assume o comitê provisório para a direção da seção até a eleição da nova comissão executiva, em 28 de novembro de 1918. Em $1^{\circ}$ de junho de 1919, funda o L'Ordine Nuovo com os colegas de Universidade e após sua guinada com o "golpe de Estado redacional", o proletariado turinense adere - de imediato - as formulações do grupo em torno do movimento dos Conselhos de Fábrica. Em maio de 1919, Gramsci assume novamente a comissão executiva da seção turinense; é neste mesmo período e no ano subsequente que se inicia em Turim, os dois anos vermelhos - o "biennio rosso" (FIORI, 1979). Em setembro de 1919, os trabalhadores da Fiat dão origem ao primeiro Conselho de Fábrica na Itália: "A constituição dos primeiros Conselhos de fábrica na Fiat significava que o princípio era perfeitamente traduzível na realidade" (FIORI, 1979, p. 154). Em abril de 1920, a classe operária entra em greve geral, ocupando o espaço das fábricas. A resposta patronal à irrupção da greve foi o ataque frontal imediato: a repressão dos policiais e da força armada levou o retorno dos trabalhadores às fábricas depois de cerca de 10 dias de resistência. É este contexto que instaurou a derrota do esforço de Gramsci e dos ordinovistas em torno da articulação do "movimento conselhista" (FIORI, 1979). Abrir-se-ia um novo capítulo na história do autor "sardo": exatamente àquele posto pela aposta da direção do processo revolucionário pelo Partido Político.

\section{CONSIDERAÇÕES FINAIS}

A teorização dos Conselhos de Fábrica por Gramsci e por seus companheiros ordinovistas indicava a extensão do terreno para a elaboração de uma teoria revolucionária a partir da absorção gradual da experiência soviética russa para o cenário particular da Itália. Desde o final de 1919, diversas interpretações emergiam no interior do PSI: no Congresso de Bolonha (sessão nacional do Partido Socialista), realizado entre os dias 5 e 8 de outubro de 1919, Amadeo Bordiga - um jovem revolucionário de Nápoles que dirigia o semanário Il Soviet - instaurava uma oposição, tanto à vertente reformista, quanto à vertente maximalista do PSI; defendia a necessidade de se construir um novo partido de vanguarda e revolucionário, cuja denominação ficou referenciada como a seção "abstencionista". É no contexto de efervescência e/ou de expansão do movimento conselhista que a cisão no interior do PSI torna a se evidenciar de maneira mais intensa: os reformistas do Partido acusam Gramsci e os ordinovistas de “anarco-sindicalistas", por supostamente serem responsáveis por minar o papel dos Sindicatos tradicionais a partir da constituição dos Conselhos de Fábrica. É assim que, quando o movimento operário e seu principal porta voz (L'Ordine Nuovo), precisavam de apoio contra a ofensiva patronal, tratam de ficar à margem e de se verem inteiramente isolados (DEL ROIO, 2005). 
Apesar do fracasso do movimento dos Conselhos de Fábrica na Itália, a experiência serviu para evidenciar para o autor "sardo" que a hegemonia proletária deve ser conquistada para além do lócus da fábrica e do terreno da produção; deve ser tomada antes e - inclusive - no espaço da representação política. O conselhismo - por seu turno - não deixou de representar uma importante construção de Gramsci para pensar e/ou avançar na elaboração de uma teoria revolucionária para a Itália. Fracassada a experiência, o autor "sardo", ainda que à custa de muita resistência, tornará mais adiante a se convencer da necessidade de romper com PSI e ingressar - como já demonstrava a proposição de Bordiga - na fundação do Partido Comunista Italiano (PCI). É partir daí que passa a conceber a necessidade de um partido revolucionário para a insurreição da revolução (COUTINHO, 1992). É este arranjo intelectual e prático da formação política de Gramsci que introduz as bases para a posterior incorporação completa da herança leniniana, condensando a assimilação direta do pensamento de Marx.

\section{REFERÊNCIAS}

CARDOSO, Juliane Helanski; SILVA, Vania Sandeleia Vaz da; NERES, Geraldo Magella. Como estudar teoria política: textualismo, contextualismo linguístico e contextualismo social. In: Anais do V Simpósio Paranaense de Ciências Sociais. UNIOESTE - Toledo/PR, 18 a 20 de maio, 2016, p. 63-85.

COUTINHO, Carlos Nelson. Gramsci: um estudo sobre seu pensamento político. Rio de Janeiro: Campus, 1992.

DEL ROIO, Marcos. Os prismas de Gramsci: a fórmula política da frente única (1919-1926). São Paulo: Xamã, 2005.

FIORI, Giuseppe. A vida de Antonio Gramsci. Tradução de Sergio Lamarão. Rio de Janeiro: Paz e Terra, 1979.

GRAMSCI, Antonio. Escritos políticos. Volume 1. Organização e tradução de Carlos Nelson Coutinho. Rio de Janeiro: Civilização Brasileira, 2004.

LAJOLO, Laurana. Antonio Gramsci: uma vida. Tradução de Carlos Nelson Coutinho. São Paulo: Editora Brasiliense, 1982.

LIGUORI, Guido; VOZA, Pasquale (Org.). Dicionário gramsciano (1926-1937). Tradução de Ana Maria Chiarini, Diego Silveira Coelho Ferreira, Leandro de Oliveira Galastri e Silva de Bernardinis. Revisão técnica de Marco Aurélio Nogueira. São Paulo: Boitempo, 2017.

NERES, Geraldo Magella. Gramsci e o "moderno príncipe": a teoria do partido nos Cadernos do Cárcere. São Paulo: Cultura Acadêmica, 2012.

RAPONE, Leonardo. O jovem Gramsci: cinco anos que parecem séculos (1914-1919). Tradução de Luiz Sérgio Henriques. Rio de Janeiro: Contraponto; Brasília, DF: Fundação Astrojildo Pereira, 2014.

\footnotetext{
${ }^{1}$ Giovanni Giolitti “[...] dirigiu quase que consecutivamente o governo de 1903 até 1914 [...] Na sua prática política Giolitti fundava sua ação de governo sobre o transformismo parlamentar e recorria fortemente ao uso da repressão
} 
estatal, particularmente contra os camponeses meridionais. Atraindo a pequena burguesia do Mezzogiorno para a administração pública, Giolitti deixou a classe camponesa completamente acéfala" (LIGUORI; VOZA, 2017, p. 336). Isto é: governou - capturando a pequena burguesia do sul - em benefício dos industriais nortistas a fim de sustentar a economia setentrional. Para tanto, abandonou e lançou os camponeses do sul na pauperização extrema: findou na história da Itália uma acentuada disparidade entre Norte industrializado e Sul agrário.

${ }^{2}$ Gramsci não negará, mesmo em seu período de maturidade, a importância das condições subjetivas para a insurreição do processo revolucionário, mas é “[...] evidente que essa valorização extremada da atuação da 'vontade' sobre a 'objetividade' no desenlace da dinâmica histórica seria posteriormente corrigida [...] Assim como a compreensão mais aprofundada do bolchevismo mostraria a insuficiência do voluntarismo juvenil de Gramsci diante da complexa articulação dialética entre condições objetivas e objetivas presentes no desenvolvimento das mudanças sociais" (NERES, 2012, p. 70).

${ }^{3}$ Investigar o processo de transição de Gramsci à maturidade é de extrema importância para a apreensão do movimento de suas construções teóricas. Trazê-la à baila neste artigo é, no entanto, inferência que foge aos seus próprios objetivos; para o aprofundamento desta discussão ver Coutinho (1992) e Neres (2012). 